\title{
PACAP Neurons in the Hypothalamic Ventromedial Nucleus Are Targets of Central Leptin Signaling
}

\author{
Zoe Hawke, ${ }^{1}$ Tina R. Ivanov, ${ }^{1}$ David A. Bechtold, ${ }^{1}$ Harveen Dhillon, ${ }^{2}$ Brad B. Lowell, ${ }^{2}$ and Simon M. Luckman ${ }^{1}$ \\ ${ }^{1}$ Faculty of Life Sciences, University of Manchester, Manchester M13 9PT, United Kingdom, and 2Division of Endocrinology, Department of Medicine, Beth \\ Israel Deaconess Medical Center and Harvard Medical School, Boston, Massachusetts 02215
}

The adipose-derived hormone, leptin, was discovered over 10 years ago, but only now are we unmasking its downstream pathways which lead to reduced energy intake (feeding) and increased energy expenditure (thermogenesis). Recent transgenic models have challenged the longstanding supposition that the hypothalamic arcuate nucleus (Arc) is omnipotent in the central response to leptin, and research focus is beginning to shift to examine roles of extra-arcuate sites. Dhillon et al. (2006) demonstrated that targeted knock out of the signaling form of the leptin receptor (lepr-B) in steroidogenic factor 1 (SF-1) cells of the hypothalamic ventromedial nucleus (VMN) produces obesity of a similar magnitude to the pro-opiomelanocortin (POMC)-driven lepr-B deleted mouse, via a functionally distinct mechanism. These findings reveal that SF-1 cells of the VMN could be equally as important as POMC cells in mediating leptin's anti-obesity effects. However, the identification of molecular and cellular correlates of this relationship remains tantalizingly unknown. Here, we have shown that mRNA expression of the VMN-expressed neuropeptide pituitary adenylate cyclase-activating polypeptide (PACAP) is regulated according to energy status and that it exerts catabolic effects when administered centrally to mice. Furthermore, we have shown that SF-1 and PACAP mRNAs are colocalized in the VMN, and that leptin signaling via lepr-B is required for normal PACAP expression in these cells. Finally, blocking endogenous central PACAP signaling with the antagonist $\mathrm{PACAP}_{6-38}$ markedly attenuates leptin-induced hypophagia and hyperthermia in vivo. Thus, it appears that PACAP is an important mediator of central leptin effects on energy balance.

\section{Introduction}

The hormone leptin exerts the vast majority of its metabolic effects via the CNS (Cohen et al., 2001; Kowalski et al., 2001). The signaling form of its receptor, lepr-B, is expressed in a number of brain sites, but most abundantly in hypothalamic nuclei that regulate energy homeostasis, including the arcuate nucleus (Arc), dorsomedial hypothalamic nucleus (DMN), lateral hypothalamic area (LH), and the ventromedial hypothalamic nucleus (VMN) (Mercer et al., 1996; Schwartz et al., 1996; Elmquist et al., 1997, 1998). While many models of leptin action have put principal emphasis on neurons of the Arc, recent data have revealed that POMC-specific lepr-B knock-out mice do not exhibit the morbid obesity and other defects characteristic of $o b / o b$ (Bray and York, 1979; Zhang et al., 1994; Lee et al., 1996) or $d b / d b$ mice, implicating extra-arcuate sites, including the VMN, in leptin responses (Balthasar et al., 2004).

Leptin signaling in the VMN plays an important role in regulation of energy homeostasis. Exogenous leptin treatment induces c-Fos protein expression and STAT3 phosphorylation in VMN neurons (Elmquist et al., 1997; Hübschle et al., 2001; Frontini et al., 2008) and extracellular electrophysiological recordings reveal that approximately half of all VMN neurons re-

Received March 26, 2009; revised Aug. 14, 2009; accepted Sept. 11, 2009.

This work was funded by the Biotechnology and Biological Sciences Research Council and supplemented by the British Pharmacological Society Integrative Pharmacology Fund.

Correspondence should be addressed to Simon Luckman, AV Hill Building, Faculty of Life Sciences, University of Manchester, 0xford Road, Manchester M13 9PT, UK. E-mail: simon.luckman@manchester.ac.uk.

DOI:10.1523/JNEUROSCI.1526-09.2009

Copyright $\odot 2009$ Society for Neuroscience $\quad 0270-6474 / 09 / 2914828-08 \$ 15.00 / 0$ spond to leptin (Irani et al., 2008). Zhao and colleagues demonstrated that targeted deletion of the VMN transcription factor steroidogenic factor 1 (SF-1) results in agenesis of the VMN and obesity (Majdic et al., 2002; Zhao et al., 2004). The SF-1 promoter has since been used to drive expression of Crerecombinase, to selectively knock out "floxed" genes in the VMN. Most notably, SF-1-driven deletion of lepr-B results in an obese phenotype, similar in severity to that observed in POMC-Cre lepr ${ }^{\text {flox/flox }}$ mice (Dhillon et al., 2006). Moreover, lepr-B knock out in both POMC and SF-1 cells has an additive effect, increasing the obesity seen in either single mutant. These data imply that, far from being subordinate to the Arc, the VMN may impose just as much influence on central leptin signaling.

Despite compelling evidence for a role of the VMN in energy balance, phenotypic characterization of its cell populations remains poorly described. Like many hypothalamic neurons, at least some of the effects of SF- 1 cells in the VMN are mediated by glutamate (Tong et al., 2007), although neuropeptidergic classifications remain elusive. Microarray studies have identified a number of VMN-enriched genes, including the neuropeptide pituitary adenylate cyclase-activating polypeptide (PACAP) (Segal et al., 2005; Kurrasch et al., 2007), which has been implicated in many central functions (for review, see Vaudry et al., 2000). The pleiotropic nature of this peptide has made it difficult to study in terms of energy balance; however, in this study, we have shown by in vivo pharmacological and histological methods that the VMN PACAP population partially mediates responses to leptin, and that PACAP exerts robust effects on both appetite and energy expenditure in mice. 


\section{Materials and Methods}

Subjects. Unless otherwise stated, experiments were performed using adult male CD-1 mice (35-40 g, Harlan). Animals were maintained on a $12: 12 \mathrm{~h} \mathrm{light} /$ dark cycle at $22 \pm 1{ }^{\circ} \mathrm{C}$ with $45 \pm 10 \%$ humidity at University of Manchester, UK. All experiments were performed in accordance with the UK Animals (Scientific Procedures) Act (1986).

Dietary manipulations. Mice were group housed with ad libitum access to water. Food was removed at 10:00 A.M. and animals were subsequently food-deprived for $48 \mathrm{~h}$. Half were given daily intraperitoneal injections of recombinant murine leptin $(2 \mathrm{mg} / \mathrm{kg})$, and half sterile isotonic saline at 8:00 P.M. for the duration of the fast. A control group was not fasted and also received saline ( $n=7$ per group). A separate cohort of mice received high-energy diet (HED; $60 \mathrm{kcal} \%$ fat; D12492 Research Diets) for 8 weeks, beginning at 8 weeks old. A control group remained on normal chow throughout this period ( $n=8$ per group).

Surgical procedures. For cannulation of the lateral ventricle, animals were maintained under anesthesia with 1-2\% isoflurane in oxygen (500 $\mathrm{ml} / \mathrm{min}$ ). A sterilized guide cannula was inserted to the depth of $1.0 \mathrm{~mm}$, $0.2 \mathrm{~mm}$ posterior and $1.0 \mathrm{~mm}$ lateral to bregma and fixed in position using acrylic dental cement (Kemdent) adhered to a jeweler's screw. For implantation of remote radio telemetry transmitters, animals were anesthetized as above and a precalibrated, sterile radio transmitter (TA-F20 Data Sciences International) was inserted into the peritoneal cavity. Following surgery, mice were singly housed and given 1 week to fully recover before being used in any experiment.

Assessment of food intake and body weight. For fast-induced refeeding, mice were food deprived from 4:00 P.M., and between 10:00 and 10:30 A.M. the following day freely behaving mice were injected into the lateral ventricle (a depth of $2 \mathrm{~mm}$ below the skull surface; intracerebroventricularly) with $1 \mu \mathrm{l}$ of sterile isotonic saline or drug over a period of $1 \mathrm{~min}$ (recombinant murine PACAP 15 pmol, $30 \mathrm{p} \mathrm{mol,} 60$ pmol, recombinant murine PACAP $_{6-38} 0.3 \mathrm{nmol}$, both Bachem; $n=6-10$ per group). Weighed food was immediately returned, and food intake monitored at $1,2,4$, and $24 \mathrm{~h}$ postinjection. For nocturnal feeding, mice were weighed and given an intracerebroventricular injection of drug (PACAP, PACAP $_{6-38}$ or recombinant murine leptin, 60 pmol, Peprotech EC; all diluted in sterile isotonic saline) or sterile isotonic saline at lights off and preweighed food was immediately returned and monitored as before. Body weight was taken at $24 \mathrm{~h}$ postinjection. For the pair feeding experiment, the following night, a naive group were weighed and intracerebroventricularly injected with $1 \mu \mathrm{l}$ of sterile isotonic saline, and then pair-fed with the mean quantity of chow as had been consumed by the PACAP-injected animals over the previous $24 \mathrm{~h}(n=6)$. Body weights were recorded at $24 \mathrm{~h}$ postinjection.

Behavioral satiety sequence. Mice were singly housed in transparent cages following surgery and were food deprived from 4:00 P.M. on the day before injection. Between 10:00 and 10:15 A.M. the following day animals were injected intracerebroventricularly with PACAP or sterile isotonic saline ( $n=4$ per group). Food was then returned and behavior observed and recorded at $30 \mathrm{~s}$ intervals for $90 \mathrm{~min}$. Behavior categories were established beforehand and were as follows: feeding, drinking, active, inactive, grooming, and resting (supplemental Fig. 1, available at www.jneurosci.org as supplemental material).

Assessment of core body temperature and oxygen consumption. Core body temperature (CBT) and volume of oxygen consumption $\left(\mathrm{VO}_{2}\right)$ were recorded simultaneously. Animals were singly housed in metabolic chambers with ad libitum access to normal chow and water throughout the experiment. Oxygen consumption was measured using indirect calorimetry at $10 \mathrm{~min}$ intervals (CLAMS system, Columbus Instruments). Chronically implanted radio transmitters were detected by individual receiving pads, positioned underneath each metabolic cage and signal converted to temperature readouts by an external processor (Dataquest Art v2.3, Data Sciences International). Following an acclimatization period of $>24 \mathrm{~h}$, animals were injected intracerebroventricularly with sterile isotonic saline or drug at 10:00 A.M. and monitored for $24 \mathrm{~h}$ ( $n=6-12$ per group).

$\mathrm{ob} / \mathrm{ob}$ and SF-1-Cre lepr flox/flox mice. Eight-week-old male ob/obC57BL/6 mice (Harlan) were given daily intraperitoneal injections of recombinant murine leptin $(2 \mathrm{mg} / \mathrm{kg})$, or sterile isotonic saline at 10:00 A.M. for $5 \mathrm{~d}$. $o b / w t$ littermate controls received daily injections of sterile isotonic saline ( $n=8$ per group). SF-1-Cre lepr ${ }^{\text {flox/flox }}$ and control lepr ${ }^{\text {flox/flox }}$ (Dhillon et al., 2006; $n=7$ per group) were bred from founders in the University of Manchester Biological Support Facility and killed at 8 weeks old. Animals used for comparison were males from two litters of the same generation to minimize confounding effects of mixed strain background.

Dual-label ribonucleotide in situ hybridization histology. Naive mice were killed by cervical dislocation between 10:00 and 12:00 A.M. and brains were quickly removed and frozen on dry ice. Fifteen micrometer cryostat hypothalamic sections were thaw-mounted onto Polysine slides (Menzel and Glaser), and stored at $-80^{\circ} \mathrm{C}$ until use. Sections were fixed using $4 \%$ paraformaldehyde in $0.1 \mathrm{~m}$ phosphate buffer (PB), then treated with $0.25 \%$ acetic anhydride in $0.1 \mathrm{M}$ triethanolamine $\mathrm{HCl} / 0.9 \% \mathrm{NaCl}$ for $10 \mathrm{~min}$, dehydrated in increasing concentrations of ethanol, delipidated in $100 \%$ chloroform, and air dried. Sections were then hybridized with a mixture of PACAP ${ }^{33} \mathrm{P}$-conjugated $\left(1 \times 10^{6}\right.$ counts $\left./ \mathrm{ml}\right)$, and SF-1 digoxygenin (DIG)-conjugated $(300 \mathrm{ng} / \mathrm{ml})$ probes in buffer $(4 \times$ SSC; $50 \%$ deionized formamide, $1 \mathrm{~mm}$ EDTA, $20 \mu \mathrm{g} / \mathrm{ml}$ yeast tRNA, $10 \%$ dextran sulfate, $1 \times$ Denhardt's solution; all Sigma Aldrich). Riboprobe details are as follows: PACAP mRNA bases 506-980; 494b. SF-1 mRNA bases $2038-2870 ; 847 \mathrm{~b}$. Hybridization took place at $65^{\circ} \mathrm{C}$ overnight and sections were then rinsed in $2 \times \mathrm{SSC}$ at room temperature $(\mathrm{RT})$, then $2 \times$ SSC, $2 \times \mathrm{SSC} / 50 \%$ formamide, and $0.5 \times \mathrm{SSC}$, all at $60^{\circ} \mathrm{C}$. Sections were then washed $0.1 \mathrm{~m}$ Tris-buffered saline (TBS pH 7.5) and blocked using fetal calf serum in TBS-T (TBS pH 7.5, 0.1\% Triton). Slides were then incubated at $4^{\circ} \mathrm{C}$ overnight in anti-digoxigenin-POD, fab fragments (Roche Diagnostics; 1:1500 in blocking buffer), then washed again in TBS $\mathrm{pH} 7.5$, followed by two further washes in $0.1 \mathrm{~m}$ Tris $\mathrm{pH} 9.5,0.1 \mathrm{M} \mathrm{NaCl}, 50$ $\mathrm{mm} \mathrm{MgCl}$. Bound DIG-probe was detected using NBT-BCIP (Roche Diagnostics, 1:100 in buffer 2) and slides were thoroughly washed and air-dried before coating in emulsion solution (K5; Ilford Imaging). Emulsion dipped slides were stored at $4^{\circ} \mathrm{C}$ for 8 weeks and then developed and fixed using Ilford imaging reagents (1:5 Phenisol, 1:5 Hypam, Ilford Imaging). Slides were then air dried and coverslipped using xylene-based mounting medium. A neuron was considered positive for SF-1 if the cell body was clearly DIGlabeled (purple stain) and PACAP positive if its cell body was decorated with at least 10 silver grains $(3 \times$ above background).

Semiquantitative oligonucleotide in situ hybridization histology. Mouse hypothalamic sections were processed as for ribonucleotide in situ hybridization, except sections were not delipidated in chloroform. An antisense PACAP oligonucleotide (sequence: CAGTCACTGTCTGGAGCTGGTGTCTGGAGAGAAGCC) was end-labeled with ${ }^{35}$ S-dATP by incubation with terminal deoxynucleotydyl transferase (TdT; Promega). Unincorporated nucleotides were removed using MicroSpin G-25 columns (GE Healthcare) according to kit instructions. Sections were hybridized at $37^{\circ} \mathrm{C}$ overnight, with hybridization buffer $(4 \times$ SSC, 500 $\mu \mathrm{g} / \mathrm{ml}$ salmon testes DNA, 2\% Denhardt's solution, 2.5\% dextran sulfate, $50 \%$ deionized formamide and $0.3 \% \beta$-mercaptoethanol) containing $1 \times 10^{6}$ counts per $\mathrm{ml}$ labeled oligonucleotide. Slides were washed three times in $1 \times \mathrm{SSC}$ at $55^{\circ} \mathrm{C}$, followed by $1 \mathrm{~h}$ at room temperature in the same buffer. Slides were dipped briefly in $300 \mathrm{~mm}$ ammonium acetate, followed by $70 \%$ ethanol, air dried and exposed to Kodak Biomax film and stored at $4^{\circ} \mathrm{C}$ for $4-6$ weeks. Region-specific optical density data were collected using Leica-Qwin imaging software and normalized to background.

Statistical analysis. Datasets were analyzed using Graphpad Prism software (version 4) using an unpaired Student's $t$ test where two groups only were compared, or one-way ANOVA followed by Dunnett's or Newman-Keuls post hoc tests where three or more groups were compared. Nonparametric Pearson correlation was performed to compare individual body weights with relative PACAP expression in the HED experiment. $p<0.05$ was considered statistically significant.

\section{Results}

\section{SF-1 cells of the dorsomedial VMN express PACAP}

Previous electrophysiological recordings from SF-1 neurons, preidentified by their expression of green-florescent protein, reported that $82 \%$ SF-1-positive cells tested were depolarized by 


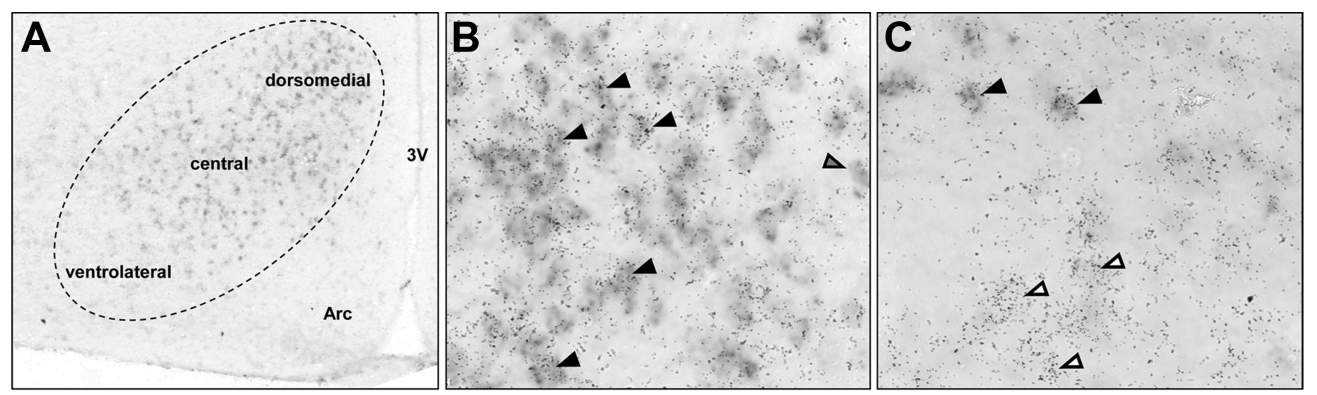

Figure 1. Colocalization of SF-1 and PACAP in the VMN. Dual in situ hybridization histology was performed on mouse VMN. Gray arrow, SF-1 mRNA only; white arrows, PACAP mRNA only; black arrows, SF-1 and PACAP mRNA colocalization. A, SF-1 mRNA signal in the dorsomedial, central and ventrolateral subdivisions of the VMN. B, Dual detection of SF-1 (gray cell bodies) and PACAP (silver grains) mRNA in the dorsomedial VMN. C, Dual detection of SF-1 and PACAP mRNA in the ventrolateral VMN.

Table 1. Colocalization of SF-1 and PACAP in the VMN

\begin{tabular}{lccl}
\hline VMN subdivision & SF-1 only & PACAP only & SF-1 and PACAP \\
\hline Dorsomedial & $9 \pm 1 \%$ & $8 \pm 1 \%$ & $83 \pm 1 \%$ \\
Central & $8 \pm 1 \%$ & $14 \pm 0.5 \%$ & $77 \pm 3 \%$ \\
Ventrolateral & $2 \pm 1 \%$ & $48 \pm 5 \%$ & $51 \pm 2 \%$ \\
\hline
\end{tabular}

Summary of the percentage of detected VMN cells that express SF-1 only, PACAP only, or both SF-1 and PACAP mRNA.

leptin (Dhillon et al., 2006), suggesting they are likely to be of a "catabolic" nature (perhaps functioning to reduce feeding and to increase energy expenditure). In the present study, dual-label in situ hybridization histology showed that in the dorsomedial and central VMN subdivisions PACAP mRNA is expressed in nearly all SF-1-positive cells ( $90 \pm 2 \%$ and $91 \pm 1 \%$ respectively) (Fig. 1 ; Table 1), allowing us to conclude that a major population of leptin-sensitive neurons contain PACAP. Conversely, while the majority of PACAP-positive cells in the dorsomedial and central VMN contain SF-1, the overlap of the two markers in the ventrolateral $\mathrm{VMN}$ is less striking and may underlie functional differences between the regions.

\section{The expression of PACAP in the VMN is regulated according to energy status}

Having postulated that PACAP-containing neurons are a target for leptin we would expect them to be sensitive to energy status. We used $48 \mathrm{~h}$ food deprivation and diet-induced obesity (DIO) as contrasting experimental paradigms, to investigate whether PACAP expression in the VMN undergoes plastic changes in response to energy balance signals. Mice fasted for $48 \mathrm{~h}$ lost $11 \pm$ $0.5 \%$ of their original body weight if given saline and $13 \pm 1 \%$ with leptin replacement (both $p<0.001$ compared with fed controls) (supplemental Fig. $1 A$, available at www.jneurosci.org as supplemental material). Recently, Mounien et al. (2009) demonstrated using rtPCR that total hypothalamic PACAP mRNA is reduced following $48 \mathrm{~h}$ fasting in mice. Using a similar paradigm, our semiquantitative in situ hybridization reveals a VMN-specific downregulation of PACAP expression compared with nonfasted mice $(-39 \pm 2 \%, p<0.001)$ (Fig. $2 B$ ), which can be prevented by leptin replacement. No differences were observed in the medial habenula (mHab), which was used as a comparison region for analysis. These results show that fasting induces a rapid decrease in VMN PACAP expression, presumably as a result of the low leptin levels that typify this condition.

Shifts in energy balance in the opposite direction, i.e., obesity, represent a much more complex physiological state, the mechanisms of which remain largely obscure. 8 weeks on HED caused weight gain of $39 \pm 5 \%$ compared with $17 \pm 1 \%$ in the control chow group $(p<0.001)$ (supplemental Fig. $1 B$, available at www.jneurosci.org as supplemental material). However, as has been reported previously (Levin et al., 1997; Archer et al., 2003; Koza et al., 2006; Enriori et al., 2007), there was marked variation in susceptibility to weight gain on high energy diet, with some individuals gaining no more that those on control diet. Group data showed that HED-fed mice had increased VMN PACAP expression compared with chow-fed controls $(+52 \pm 14 \%, p<$ 0.01) (Fig. 2Ci). Spearman correlation analysis of body weight versus relative PACAP expression revealed a significant positive correlation in the normal chow controls ( $p<0.05, r=0.86)$ (Fig. $2 \mathrm{Cii}$ ) and a significant negative correlation in the HED-fed mice $(p<0.01, r=-0.95)$ (Fig. 2Ciii). These data imply that VMNspecific upregulation of PACAP expression could form part of the physiological counter regulation which prevents DIO.

To further investigate the effects of leptin on PACAP expression we have used two genetic models of defective leptin signaling. Homozygous genetic deletion of the $o b$ gene results in a well documented morbidly obese phenotype, and abnormalities in metabolic rate, thermogenesis and sexual function (Zhang et al., 1994). ob/ob mice have vastly distorted hypothalamic energy balance pathways, with abnormalities in BDNF, NPY and POMC mRNA expression (Morley et al., 1995; Thornton et al., 1997; Schwartz et al., 1998; Komori et al., 2005), and atypical synaptic architecture (Pinto et al., 2004). Exogenous leptin rapidly ameliorates these defects, resulting in normal metabolic rate, appetite and body weight (Pelleymounter et al., 1995; Hwa et al., 1997). We determined whether lack of leptin, and subsequent leptin replacement affects PACAP expression in $o b / o b$ mice, as it does in the fasting paradigm. At the start of the experiment $o b / o b$ mice were $56 \pm 2 \%$ heavier than their lean, heterozygous littermates, which were used as controls. Leptin-injected $o b / o b$ mice lost weight steadily over the course of the experiment, and on day 5 were significantly lighter than the $o b / o b$ group receiving saline $(-10 \pm 3 \%$ ) (supplemental Fig. $1 C$, available at www.jneurosci. org as supplemental material). ob/ob mice, similar to fasted wildtype mice, showed significantly lower PACAP expression in the VMN $(-32 \pm 5 \%$ compared with $o b / w t, p<0.001)$ (Fig. $2 D)$. Furthermore, despite relatively modest weight loss, VMN PACAP expression in the leptin-treated group was restored to that of lean controls. PACAP expression levels were similar in the mHab of all three groups, suggesting that leptin modulates PACAP expression selectively in the VMN.

The SF-1-Cre lepr ${ }^{\text {flox/flox }}$ strain lacks lepr-B selectively in SF-1 cells (Dhillon et al., 2006). This model provides further insight into leptin signaling within the VMN, since extra-VMN leptin targets, such as the Arc, DMN and $\mathrm{LH}$ remain intact. In contrast with $o b / o b$, SF-1-Cre lepr ${ }^{\text {flox/flox }}$ mice display only a mild obese 
A

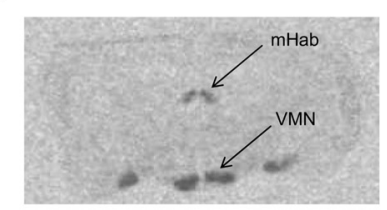

B

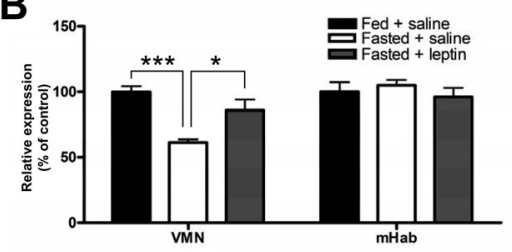

C (i)

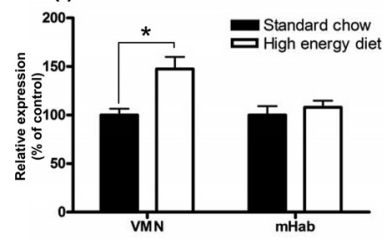

(ii)

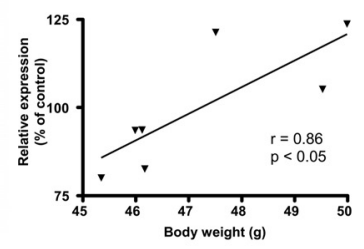

(iii)
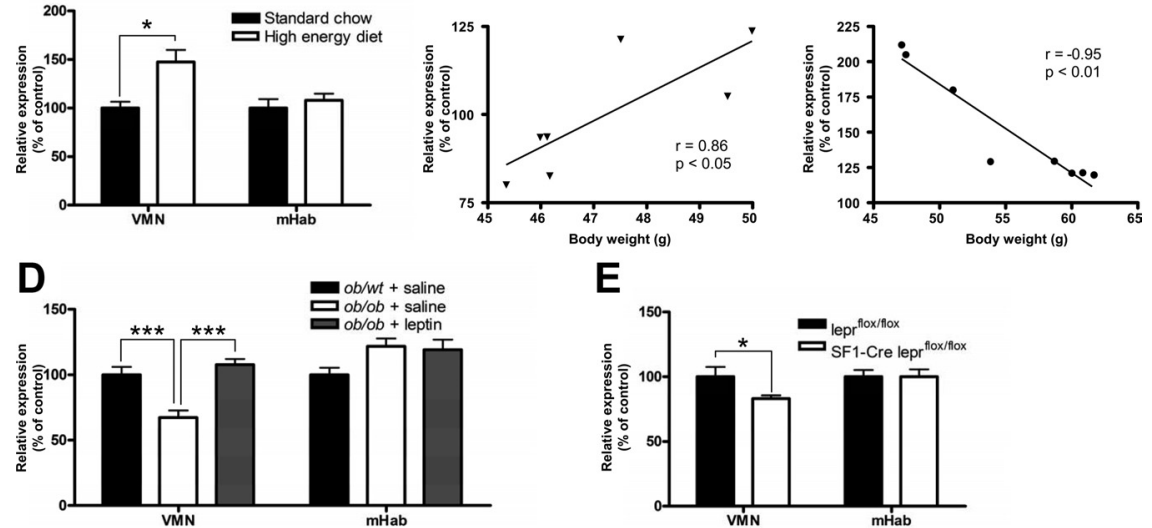

$\mathbf{E}$

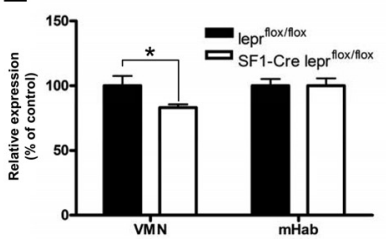

Figure 2. Effects of metabolic stimuli on expression of PACAP mRNA. Semiquantitative in situ hybridization histology was performed on brain sections from wild-type and mutant mice that had undergone various metabolic stimuli. VMN and $\mathrm{mHab}$ PACAP mRNA expression levels were compared. Data are expressed as mean $\pm S E M$. $A$, Representative autoradiograph showing PACAP oligoprobe hybridization. B, Saline-treated fed versus saline or leptin-treated 48-h-fasted CD-1 mice. C, Eight weeks of high-energy diet began at the age of 8 weeks. $i$, HED-fed versus chow-fed CD-1 mice. ii, iii, Correlation between body weight and PACAP expression in (ii) chow-fed and (iii) HED-fed mice. D, Saline-treated ob/wt versus saline or leptin-treated ob/ob mice. $\boldsymbol{E}$, SF-1-Cre lepr ${ }^{\text {flox/flox }}$ versus lepr ${ }^{\text {flox/flox }}$ mice. ${ }^{*} p<0.05,{ }^{* * *} p<0.001$.

phenotype, with relatively normal food intake and metabolic rate. These mice, therefore, are a useful model for studying VMNspecific leptin actions, without any confounding effects of morbid obesity. Young adults were used for this experiment as they were not yet significantly different in weight from the relevant transgenic controls (lepr ${ }^{\text {flox/flox }}$ ) (supplemental Fig. $1 D$, available at www.jneurosci.org as supplemental material). SF-1-Cre lepr ${ }^{\text {flox/flox }}$ mice have significantly lower PACAP expression in the VMN than controls $(-21 \pm 4 \%, p<0.05)$ (Fig. $2 E$ ). This is not to the degree observed in either fasted or leptin-deficient animals, but provides evidence that leptin action specifically through SF-1-positive cells in the VMN has effects on PACAP expression. PACAP levels were normal in the $\mathrm{mHab}$ of the conditional knock-out mice.

\section{PACAP induces hypophagia and thermogenesis via $\mathrm{PAC}_{1}$ receptors}

Numerous studies have reported on the anorexigenic effects of PACAP in vivo (Morley et al., 1992; Mizuno et al., 1998; Tachibana et al., 2003; Matsuda et al., 2005; Mounien et al., 2009), but it has not yet been established if these effects are physiologically relevant. PACAP has been implicated in a number of centrally mediated functions, including circadian entrainment to light, neuronal development and protection, and the stress response to infection (for review, see Vaudry et al., 2000), hence reduced food intake may be secondary to any of these responses. It is also noteworthy that exogenously administered peptides can have nonspecific effects that are distinct from receptor binding. We have taken measures in our experimental design, particularly the use of behavioral satiety sequence (BSS) analysis, to test these possibilities.

PACAP administered intracerebroventricularly significantly reduced fast-induced refeeding compared with saline at doses of 60 and $30 \mathrm{pmol}$, but not at $15 \mathrm{pmol}(-82 \pm$ $11 \%,-36 \pm 9 \%,-13 \pm 3 \%$ respectively at $1 \mathrm{~h})$ (Fig. 3A). Effects were seen at 1, 2, and $4 \mathrm{~h}$ postinjection, with the highest dose $(60$ pmol) producing persistent anorexia over $24 \mathrm{~h}$. To determine whether food intake was being reduced by a homeostatic mechanism, BSS analysis was performed using each of the doses. Agents which reduce food intake by sedative or aversive effects cause marked disturbance of the BSS pattern, whereas true satiety factors do not alter the overall sequence of behaviors (Antin et al., 1975; Halford et al., 1998). BSS analysis revealed a disruption of the behavior sequence following $60 \mathrm{pmol}$ of PACAP, with the majority of time being spent "inactive." By comparison, 15 and 30 pmol doses did not disrupt the overall pattern of the BSS, but did significantly alter time spent in certain behaviors, as expected for such a pleiotropic peptide (Table 2; supplemental Fig. 2, available at www.jneurosci.org as supplemental material). Based on feeding and BSS dose responses, 30 pmol was selected as optimal for subsequent experiments, as the highest dose to produce robust anorexia with minimal adverse effects.

PACAP at this dose also significantly decreased nocturnal food intake when injected just before lights off, more potently than in the fasted, daytime paradigm. PACAP-injected animals lost $11 \pm 3 \%$ body weight $(p<0.01)$, whereas saline-injected pair-fed mice lost significantly less weight $(p<0.05)$ (Fig. $3 B)$. Reduced food intake, therefore, cannot fully account for PACAPinduced weight loss, prompting investigation into PACAP's effect on energy expenditure. To examine this directly, we injected nonfasted mice during the mid-morning to ensure a low baseline in our control group. PACAP-injected mice showed transient increases in CBT $\left(+1 \pm 0.2^{\circ} \mathrm{C}\right)$ and $\mathrm{VO}_{2}(+339 \pm 54 \mathrm{mg} / \mathrm{kg} / \mathrm{h})$ over control levels (Fig. 3C,D), which were significant between 1 and $6 \mathrm{~h}$ postinjection. Since the $24 \mathrm{~h}$ group means are not significantly different, we can assume that the effects of a single dose of PACAP on energy expenditure are short term. These data confirm that PACAP not only decreases appetite, but also increases metabolic rate. This could account for the more pronounced loss in body weight observed in PACAP-injected mice, compared with pair-fed control mice.

Binding assays show that PACAP acts predominately at the PACAP-specific $\mathrm{PAC}_{1}$ receptor (Gourlet et al., 1995), but also binds at the VPAC receptors, which recognize a related peptide, vasoactive intestinal peptide (VIP). In mammals it is likely that PACAP exerts many of its effects through the $\mathrm{PAC}_{1}$ receptor, demonstrated by the striking phenotypic similarities between PACAP- and PAC $_{1}$-knock-out mice (Hashimoto et al., 2000) but not $\mathrm{VPAC}_{1}$ - or $\mathrm{VPAC}_{2}$-knock-out mice (Hughes et al., 2004; Bechtold et al., 2008). Furthermore, since equivalent intracerebroventricular doses of VIP cause no significant changes in food intake or CBT (S. M. Luckman and Z. Hawke, unpublished observations), it is likely that the effects of PACAP are mediated by $\mathrm{PAC}_{1}$. It was recently shown that PACAP-induced anorexia can be blocked by $\mathrm{PACAP}_{6-38}$, a potent PACAP antagonist with high affinity for $\mathrm{PAC}_{1}$ (Mounien et al., 2009). We have shown that 
coadministration of 0.3 nmol of PACAP $_{6-38}$ and 30 pmol of PACAP, results in full reversal of the anorexic, and also thermogenic effects observed when PACAP is given alone (Fig. 4). PACAP $_{6-38}$ alone had no significant effect on either food intake or CBT in this experimental paradigm. This suggests that PACAPinduced effects on energy balance are a result of action at the $\mathrm{PAC}_{1}$ receptor, as opposed to VPAC-mediated or nonspecific responses.

The responses to leptin are mediated, in part, through PACAP signaling

Single, central injection of leptin acutely affects both food intake and CBT in rats and mice, and administration of antagonists to leptin target pathways can reduce the magnitude of these effects (Seeley et al., 1997; Gardner et al., 1998; Uehara et al., 1998). Here, we investigated whether blocking endogenous PACAP receptors can prevent the acute, centrally mediated effects of leptin on food intake, body weight and CBT. An intracerebroventricular dose of 60 pmol of leptin significantly attenuated nocturnal food intake $(-56 \pm$ $5 \%$ compared with saline controls at $2 \mathrm{~h}$, $p<0.001$ ) (Fig. 5A) and body weight $(-3 \pm 1 \%$ change over $24 \mathrm{~h}$, compared with $+1.5 \pm 1 \%$ change in the control group). Coadministration of $0.3 \mathrm{nmol}$ of $\mathrm{PACAP}_{6-38}$, to antagonize $\mathrm{PAC}_{1}$ receptors, significantly reduced the magnitude of these effects (Fig. 5A). PACAP ${ }_{6-38}$ had no significant effects when given alone. Central leptin injection in the daytime resulted in an elevation of CBT over controls that was statistically significant between 1 and $6 \mathrm{~h}$ postinjection $(+0.9 \pm$ $0.2^{\circ} \mathrm{C}$ compared with controls, $p<0.01$ ) (Fig. 5B). Coadministration of $\mathrm{PACAP}_{6-38}$ significantly reduced the potency of this hyperthermic response $\left(+0.3 \pm 0.1^{\circ} \mathrm{C}\right.$ compared with controls, $\left.p<0.01\right)$ (Fig. $\left.5 B\right)$. Together with the feeding data, this provides strong evidence that PACAP forms an important downstream component of the acute effects of leptin on energy balance.

\section{Discussion}

Identifying PACAP as a VMN phenotypic marker

The VMN of the hypothalamus plays an important role in the regulation of feeding and energy homeostasis. Genetic ablation of the VMN by SF-1 knock-out results in obesity, and SF-1-targeted deletion of lepr-B produces an obese phenotype which is exacerbated by HED (Zhao et al., 2004; Dhillon et al., 2006). While the neuronal phenotypes remain to be fully classified, VMN neurons are known to respond to many peripheral indicators of energy state, including glucose, leptin, ghrelin, and insulin. However, despite convincing evidence for the importance of the VMN, few neuropeptidergic markers for specific classes of VMN neurons are available. This is in stark contrast to other hypothalamic nuclei, such as the Arc, PVN, and LH. VMN
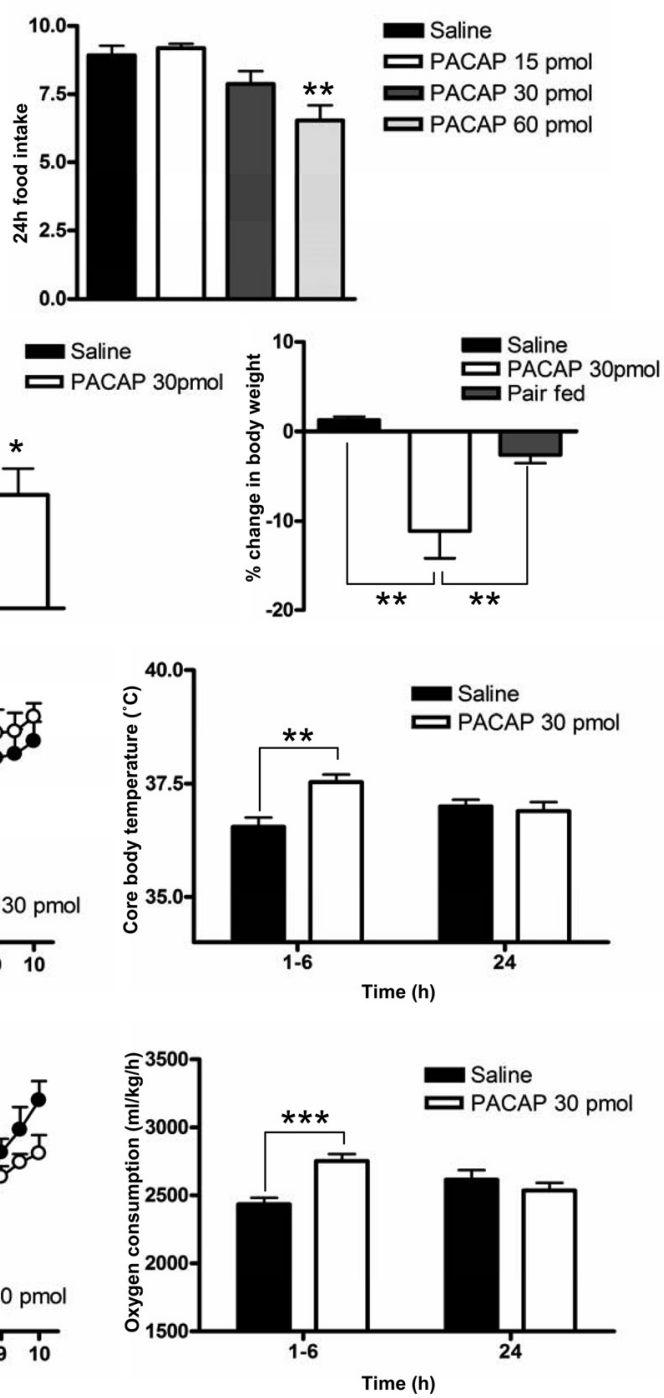

Figure 3. Effects of central PACAP injection on food intake and energy expenditure. PACAP or saline was administered intracerebroventricularly to CD-1 mice. $A$, Dose-response effect on daytime cumulative food intake following overnight food deprivation. $\boldsymbol{B}$, Nocturnal food intake and $24 \mathrm{~h}$ change in body weight of PACAP-injected versus pair fed mice. $\boldsymbol{C}$, Core body temperature of nonfasted mice. $\boldsymbol{D}, 0 x y g$ en consumption of nonfasted mice. ${ }^{*} p<0.05,{ }^{* *} p<0.01,{ }^{* * *} p<0.001$.

Table 2. Behavioral effects of a single PACAP injection

\begin{tabular}{llllrrl}
\hline & Feeding & Drinking & Activity & Inactivity & Grooming & Resting \\
\hline Saline & $19 \pm 4 \%$ & $2 \pm 0.2 \%$ & $32 \pm 4 \%$ & $2 \pm 1 \%$ & $10 \pm 2 \%$ & $33 \pm 7 \%$ \\
PACAP 15 & $20 \pm 3 \%$ & $2 \pm 0.5 \%$ & $37 \pm 9 \%$ & $10 \pm 4 \%$ & $8 \pm 2 \%$ & $22 \pm 6 \%$ \\
pmol & & & & & & \\
PACAP 30 & $9 \pm 2 \%^{*}$ & $1 \pm 0.9 \%$ & $33 \pm 5 \%$ & $23 \pm 4 \%^{* *}$ & $9 \pm 1 \%$ & $26 \pm 2 \%$ \\
$\begin{array}{c}\text { pmol } \\
\text { PACAP 60 }\end{array}$ & $8 \pm 4 \%^{*}$ & $2 \pm 0.2 \%$ & $9 \pm 4 \%^{* *}$ & $71 \pm 9 \%^{* * *}$ & $4 \pm 2 \%$ & $6 \pm 2 \%^{*}$ \\
pmol & & & & & & \\
\hline
\end{tabular}

PACAP or saline was administered intracerebroventricularly to overnight fasted CD-1 mice and food returned. Data are expressed as percentage incidences of each behavior-score over the 90 min observation session. ${ }^{*} p<0.05$, ${ }^{* *} p<0.01,{ }^{* * *} p<0.001$.

cells are predominantly glutamatergic, and Tong et al. (2007) demonstrated that blocking glutamate release from SF-1-positive cells by deletion of the glutamate vesicular transporter, VGLUT2, does not produce an obese phenotype, although it does affect counter-regulatory responses to hypoglycemia and predisposition to DIO. These findings raise the possibility that other effectors released from SF-1 neurons, for example neuropeptides, may also 
A
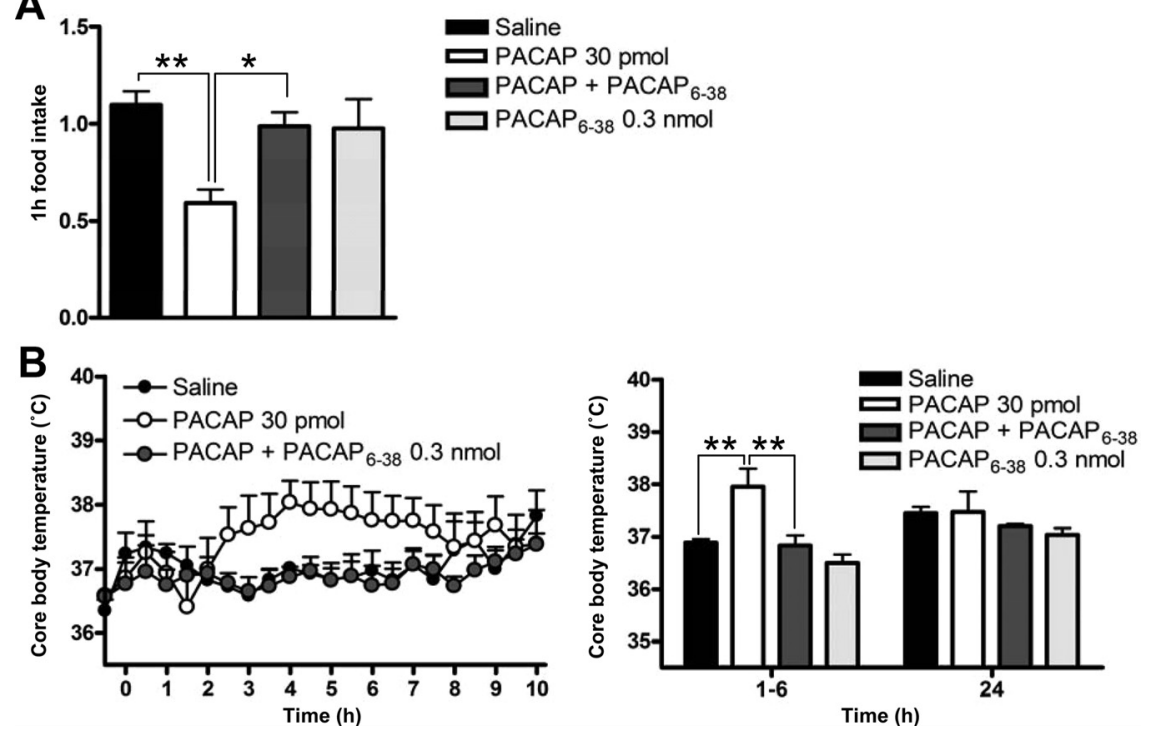

Figure 4. Coadministration of PACAP and PACAP ${ }_{6-38}$. PACAP and the $P_{1} C_{1}$ receptor antagonist PACAP ${ }_{6-38}$ were administered intracerebroventricularly in a single injection to $C D-1$ mice. $A$, Food intake following overnight food deprivation. $B$, Core body temperature of nonfasted mice. ${ }^{*} p<0.05,{ }^{* *} p<0.01$.
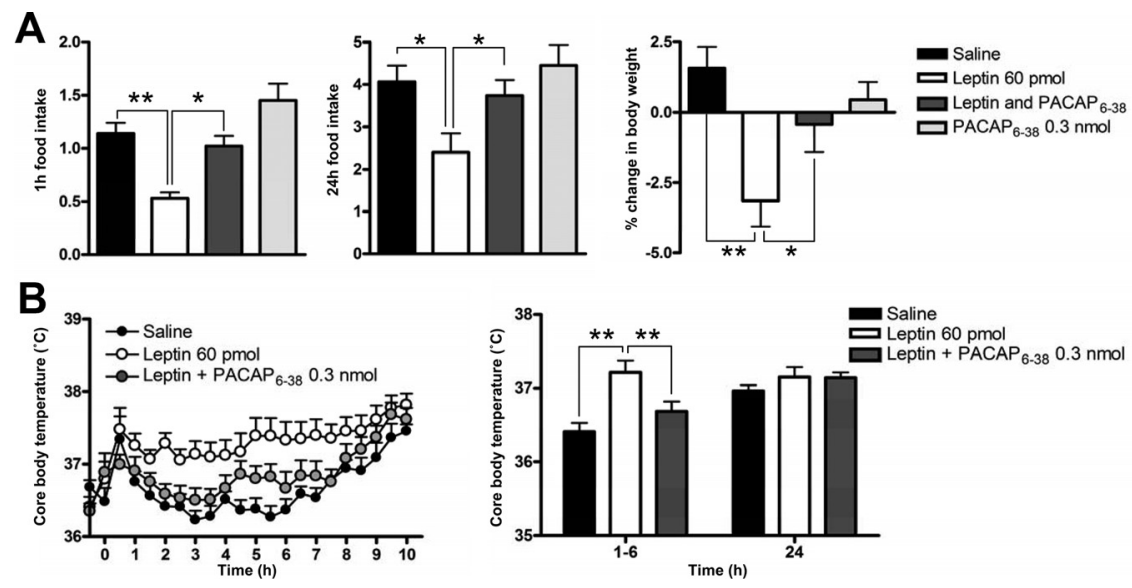

Figure 5. Coadministration of leptin and PACAP 6 6-38. Leptin and PACAP $_{6-38}$ were administered intracerebroventricularly in a single injection to $C D-1$ mice. $A$, Nocturnal food intake and $24 \mathrm{~h}$ change in body weight. $\boldsymbol{B}$, Core body temperature of nonfasted mice. ${ }^{*} p<0.05,{ }^{* *} p<0.01$.

be of importance. We investigated the metabolic role of PACAP, a pleiotropic neuropeptide, which was recently identified by microarray as a "VMN-enriched" gene (Segal et al., 2005; Kurrasch et al., 2007).

VMN PACAP neurons are likely to be a direct target for leptin Neuro-anatomical studies have led to the supposition that the Arc is the main target for processing leptin's anti-obesity effects (Spiegelman and Flier, 2001; Saper et al., 2002; Schwartz and Porte, 2005). Although the data supporting this view are persuasive, they are challenged by the fact that mice lacking lepr-B expression in POMC cells develop only moderate obesity, and mice lacking lepr-B in SF-1 cells are equally obese. Electrophysiology and immunohistochemistry confirm that SF-1 cells in the VMN are a target for leptin (Dhillon et al., 2006), and we have now shown that SF- 1 and PACAP mRNAs are colocalized in the VMN, especially in the lepr-B-rich dorsomedial region, supporting the suggestion that PACAP cells in the VMN are a leptin target.
We found that PACAP mRNA levels are significantly reduced following acute fasting and in the leptin-deficient $o b / o b$ mouse, both states of hypometabolism, increased appetite and low leptin. Moreover, we were able to restore VMN PACAP levels in both paradigms by exogenous leptin treatment. This suggests that leptin, acting either directly or indirectly, regulates PACAP expression, as it does other catabolic signaling molecules in the hypothalamus. Although PACAP cells will express lepr-B, we must also consider that the VMN has dense reciprocal connections with other hypothalamic leptin targets. To address whether expressional changes in PACAP were due to direct effects of leptin, we examined VMN PACAP levels in the SF-1-Cre lepr ${ }^{\text {flox/flox }}$ strain, which lacks lepr-B expression specifically in SF-1 neurons. As expected, we found a significant decrease in VMN PACAP expression, which suggests that direct action of leptin on SF-1 cells brings about transcriptional activation of the PACAP gene.

The development and advancement of increased adiposity is a complex phenomenon which is yet to be fully understood. Rodents (and humans) possess varying susceptibility to excessive weight gain in an obesogenic environment, with some individuals showing natural resistance (Levin et al., 1997; Jebb et al., 2006; Koza et al., 2006; Enriori et al., 2007). While a variety of mechanisms could contribute to this variability, several lines of evidence suggest that differences in the hypothalamic energy balance circuitry could be responsible. Recent characterization studies of HED-fed mice reveal impairments in adaptive thermogenesis, energy-intake control (Koza et al., 2006), glucose handling and the anorexigenic response to leptin (Enriori et al., 2007) in obese but not lean HED-fed mice. Interestingly, we found that mice that defend normal body weight on HED display a marked increase in VMN PACAP mRNA not seen in heavier HED-fed mice. This correlation leads us to infer that PACAP may be important in positive as well as negative energy balance, and could form part of the counter-regulatory response against weight gain.

\section{PACAP has effects on energy balance downstream of leptin}

Leptin exerts its effects on food intake and metabolic rate by acting on "first order" neurons in the hypothalamus. Since we have shown that VMN PACAP cells are likely to be a leptin target, we next sought to clarify the effects of central PACAP on acute energy balance, and whether these are separate, or correlated with those of leptin. We found that the effects of intracerebroventricular PACAP injection were analogous to those observed when mice are given leptin. A dose of $30 \mathrm{pmol}$ was sufficient to produce robust hypophagia, with minimal additional behavioral effects, since the BSS was not disrupted. We were then able to block this 
anorexia by coadministration with a competitive antagonist, PACAP $_{6-38}$, indicating that effects are due to receptor activation rather than a nonspecific mechanism. Moreover, blocking central PACAP receptors with PACAP $_{6-38}$ also reversed leptininduced anorexia and body weight loss. Similar studies, which demonstrated that corticotrophin-releasing hormone (CRH) and melanocortin $(\mathrm{MC})_{4}$ receptor antagonists can attenuate leptin-induced feeding effects, have been pivotal in establishing CRH and POMC as functional leptin targets (Seeley et al., 1997; Gardner et al., 1998). As such, the current findings provide strong evidence that PACAP receptors in the brain form part of leptin's downstream anorectic pathway.

In addition to its effects on food intake, leptin also impinges on energy expenditure by increasing brown-adipose tissue (BAT)-mediated thermogenesis (Collins and Surwit, 1996; Haynes et al., 1997; Hwa et al., 1997). Leptin injection either centrally or peripherally increases sympathetic nerve activity to BAT (Collins and Surwit, 1996; Haynes et al., 1997), and expression of uncoupling protein 1 (UCP-1), increasing heat production. We found a single, central leptin injection caused a transient increase in CBT, and that this response could be replicated by central PACAP injection. We had hypothesized that PACAP may affect thermogenesis, since one of the most striking features of the PACAP knock-out mouse is severely compromised cold tolerance (Arimura, 2002). Furthermore, we found that leptin and PACAP thermogenic responses form part of the same endogenous pathway, since PACAP receptor antagonism fully prevented either PACAP- or leptin-induced hyperthermia. These data suggest that PACAP is critically associated with both the thermogenic and anorexigenic effects of leptin.

\section{Possible downstream targets of PACAP-mediated effects on energy balance}

Two major roles of the VMN are thought to be the control of food intake, primarily by stimulating satiety mechanisms, and control of energy expenditure, by sympathetic activation of peripheral targets. We have provided evidence that PACAP is involved in both of these functions; however its downstream targets are yet to be identified. The VMN has reciprocal connections throughout the hypothalamus, including with the Arc and PVN, and common anorexigenic pathways involving these targets seem inevitable. Indirect evidence for interactions between PACAP and the PVN is strong. Neurons of the PVN densely express the PACAPspecific $\mathrm{PAC}_{1}$ receptor (Nomura et al., 1996), and PACAPimmunopositive terminals directly contact $\mathrm{CRH}$ and thyrotropinreleasing hormone (TRH) cell bodies of the PVN (Légrádi et al., 1997, 1998). In vivo studies in goldfish and chick have also shown that PACAP-induced anorexia is attenuated by pretreatment with CRH antagonists (Tachibana et al., 2004; Maruyama et al., 2006). Together, these data imply that the two neuropeptides form part of the same central pathway. Evidence for interaction with the melanocortin pathway is also persuasive. POMC cells of the Arc express both $\mathrm{PAC}_{1}$ and $\mathrm{VPAC}_{2}$ receptors and PACAP induces POMC expression in vitro (Mounien et al., 2006). Furthermore, pretreatment with SHU9119, an $\mathrm{MC}_{4}$ receptor antagonist, partially attenuates the anorexigenic effects of PACAP in vivo. However, since lepr-B deletion on SF-1 and POMC cells appear to cause obesity by distinct pathways (Dhillon et al., 2006), there may also be significant autonomy between PACAP- and POMC-mediated effects on energy balance.

In light of the thermogenically compromised PACAP knockout mouse, further investigation of PACAP's role in BAT activation is also justified. In the current study we have shown that
PACAP is potently thermogenic, and that its level of expression in the VMN is closely correlated with metabolic rate. As such, brain regions involved in thermogenesis represent promising PACAP targets. One such area is the periaqueductal gray, a recently identified modulator of BAT sympathetic activation. Maekawa et al. (2006) showed that around half of VMN PACAP cells project to this midbrain region, and this may be one mechanism by which endogenous PACAP acts to increase CBT and energy expenditure.

\section{Summary}

The role of the VMN in energy balance has been largely disregarded following the identification of neuropeptidergic cell populations elsewhere in the hypothalamus, yet recent transgenic models have reasserted its importance in the maintenance of normal body weight and metabolism. Here, we provide convincing evidence that PACAP cells in this nucleus are acutely responsive to alterations in energy state and that they represent an important target of central leptin action.

\section{References}

Antin J, Gibbs J, Holt J, Young RC, Smith GP (1975) Cholecystokinin elicits the complete behavioral sequence of satiety in rats. J Comp Physiol Psychol 89:784-790.

Archer ZA, Rayner DV, Rozman J, Klingenspor M, Mercer JG (2003) Normal distribution of body weight gain in male Sprague-Dawley rats fed a high-energy diet. Obes Res 11:1376-1383.

Arimura A (2002) Impaired adaptive thermogenesis in pituitary adenylate cyclase-activating polypeptide-deficient mice. Endocrinology 143:3715-3716.

Balthasar N, Coppari R, McMinn J, Liu SM, Lee CE, Tang V, Kenny CD, McGovern RA, Chua SC Jr, Elmquist JK, Lowell BB (2004) Leptin receptor signaling in POMC neurons is required for normal body weight homeostasis. Neuron 42:983-991.

Bechtold DA, Brown TM, Luckman SM, Piggins HD (2008) Metabolic rhythm abnormalities in mice lacking VIP-VPAC2 signaling. Am J Physiol Regul Integr Comp Physiol 294:R344-R351.

Bray GA, York DA (1979) Hypothalamic and genetic obesity in experimental animals: an autonomic and endocrine hypothesis. Physiol Rev 59:719-809.

Cohen P, Zhao C, Cai X, Montez JM, Rohani SC, Feinstein P, Mombaerts P, Friedman JM (2001) Selective deletion of leptin receptor in neurons leads to obesity. J Clin Invest 108:1113-1121.

Collins S, Surwit RS (1996) Pharmacologic manipulation of ob expression in a dietary model of obesity. J Biol Chem 271:9437-9440.

Dhillon H, Zigman JM, Ye C, Lee CE, McGovern RA, Tang V, Kenny CD, Christiansen LM, White RD, Edelstein EA, Coppari R, Balthasar N, Cowley MA, Chua S Jr, Elmquist JK, Lowell BB (2006) Leptin directly activates SF1 neurons in the $\mathrm{VMH}$, and this action by leptin is required for normal bodyweight homeostasis. Neuron 49:191-203.

Elmquist JK, Ahima RS, Maratos-Flier E, Flier JS, Saper CB (1997) Leptin activates neurons in ventrobasal hypothalamus and brainstem. Endocrinology 138:839-842.

Elmquist JK, Bjørbaek C, Ahima RS, Flier JS, Saper CB (1998) Distributions of leptin receptor mRNA isoforms in the rat brain. J Comp Neurol 395:535-547.

Enriori PJ, Evans AE, Sinnayah P, Jobst EE, Tonelli-Lemos L, Billes SK, Glavas MM, Grayson BE, Perello M, Nillni EA, Grove KL, Cowley MA (2007) Diet-induced obesity causes severe but reversible leptin resistance in arcuate melanocortin neurons. Cell Metab 5:181-194.

Frontini A, Bertolotti P, Tonello C, Valerio A, Nisoli E, Cinti S, Giordano A (2008) Leptin-dependent STAT3 phosphorylation in postnatal mouse hypothalamus. Brain Res 1215:105-115.

Gardner JD, Rothwell NJ, Luheshi GN (1998) Leptin affects food intake via CRF-receptor-mediated pathways. Nat Neurosci 1:103.

Gourlet P, Vandermeers A, Vandermeers-Piret MC, Rathé J, De Neef P, Robberecht P (1995) Fragments of pituitary adenylate cyclase activating polypeptide discriminate between type I and II recombinant receptors. Eur J Pharmacol 287:7-11.

Halford JC, Wanninayake SC, Blundell JE (1998) Behavioral satiety sequence (BSS) for the diagnosis of drug action on food intake. Pharmacol Biochem Behav 61:159-168. 
Hashimoto H, Shintani N, Nishino A, Okabe M, Ikawa M, Matsuyama S, Itoh K, Yamamoto K, Tomimoto S, Fujita T, Hagihara N, Mori W, Koyama Y, Matsuda T, Nagata S, Baba A (2000) Mice with markedly reduced PACAP (PAC(1)) receptor expression by targeted deletion of the signal peptide. J Neurochem 75:1810-1817.

Haynes WG, Morgan DA, Walsh SA, Mark AL, Sivitz WI (1997) Receptormediated regional sympathetic nerve activation by leptin. J Clin Invest 100:270-278.

Hübschle T, Thom E, Watson A, Roth J, Klaus S, Meyerhof W (2001) Leptin-induced nuclear translocation of STAT3 immunoreactivity in hypothalamic nuclei involved in body weight regulation. J Neurosci 21:2413-2424.

Hughes AT, Fahey B, Cutler DJ, Coogan AN, Piggins HD (2004) Aberrant gating of photic input to the suprachiasmatic circadian pacemaker of mice lacking the VPAC2 receptor. J Neurosci 24:3522-3526.

Hwa JJ, Fawzi AB, Graziano MP, Ghibaudi L, Williams P, Van Heek M, Davis H, Rudinski M, Sybertz E, Strader CD (1997) Leptin increases energy expenditure and selectively promotes fat metabolism in ob/ob mice. Am J Physiol 272:R1204-R1209.

Irani BG, Le Foll C, Dunn-Meynell A, Levin BE (2008) Effects of leptin on rat ventromedial hypothalamic neurons. Endocrinology 149:5146-5154.

Jebb SA, Siervo M, Frühbeck G, Goldberg GR, Murgatroyd PR, Prentice AM (2006) Variability of appetite control mechanisms in response to 9 weeks of progressive overfeeding in humans. Int J Obes (Lond) 30:1160-1162.

Komori T, Morikawa Y, Tamura S, Doi A, Nanjo K, Senba E (2005) Subcellular localization of glucose transporter 4 in the hypothalamic arcuate nucleus of ob/ob mice under basal conditions. Brain Res 1049:34-42.

Kowalski TJ, Liu SM, Leibel RL, Chua SC Jr (2001) Transgenic complementation of leptin-receptor deficiency. I. Rescue of the obesity/diabetes phenotype of LEPR-null mice expressing a LEPR-B transgene. Diabetes 50:425-435.

Koza RA, Nikonova L, Hogan J, Rim JS, Mendoza T, Faulk C, Skaf J, Kozak LP (2006) Changes in gene expression foreshadow diet-induced obesity in genetically identical mice. PLoS Genet 2:e81.

Kurrasch DM, Cheung CC, Lee FY, Tran PV, Hata K, Ingraham HA (2007) The neonatal ventromedial hypothalamus transcriptome reveals novel markers with spatially distinct patterning. J Neurosci 27:13624-13634.

Lee GH, Proenca R, Montez JM, Carroll KM, Darvishzadeh JG, Lee JI, Friedman JM (1996) Abnormal splicing of the leptin receptor in diabetic mice. Nature 379:632-635.

Légrádi G, Hannibal J, Lechan RM (1997) Association between pituitary adenylate cyclase-activating polypeptide and thyrotropin-releasing hormone in the rat hypothalamus. J Chem Neuroanat 13:265-279.

Légrádi G, Hannibal J, Lechan RM (1998) Pituitary adenylate cyclaseactivating polypeptide-nerve terminals densely innervate corticotropinreleasing hormone-neurons in the hypothalamic paraventricular nucleus of the rat. Neurosci Lett 246:145-148.

Levin BE, Dunn-Meynell AA, Balkan B, Keesey RE (1997) Selective breeding for diet-induced obesity and resistance in Sprague-Dawley rats. Am J Physiol 273:R725-R730.

Maekawa F, Fujiwara K, Tsukahara S, Yada T (2006) Pituitary adenylate cyclase-activating polypeptide neurons of the ventromedial hypothalamus project to the midbrain central gray. Neuroreport 17:221-224.

Majdic G, Young M, Gomez-Sanchez E, Anderson P, Szczepaniak LS, Dobbins RL, McGarry JD, Parker KL (2002) Knockout mice lacking steroidogenic factor 1 are a novel genetic model of hypothalamic obesity. Endocrinology 143:607-614.

Maruyama K, Miura T, Uchiyama M, Shioda S, Matsuda K (2006) Relationship between anorexigenic action of pituitary adenylate cyclase-activating polypeptide (PACAP) and that of corticotropin-releasing hormone (CRH) in the goldfish, Carassius auratus. Peptides 27:1820-1826.

Matsuda K, Maruyama K, Nakamachi T, Miura T, Uchiyama M, Shioda S (2005) Inhibitory effects of pituitary adenylate cyclase-activating polypeptide (PACAP) and vasoactive intestinal peptide (VIP) on food intake in the goldfish, Carassius auratus. Peptides 26:1611-1616.

Mercer JG, Hoggard N, Williams LM, Lawrence CB, Hannah LT, Trayhurn P (1996) Localization of leptin receptor mRNA and the long form splice variant $(\mathrm{Ob}-\mathrm{Rb})$ in mouse hypothalamus and adjacent brain regions by in situ hybridization. FEBS Lett 387:113-116.

Mizuno Y, Kondo K, Terashima Y, Arima H, Murase T, Oiso Y (1998) Anorectic effect of pituitary adenylate cyclase activating polypeptide (PACAP) in rats: lack of evidence for involvement of hypothalamic neuropeptide gene expression. J Neuroendocrinol 10:611-616.
Morley JE, Horowitz M, Morley PM, Flood JF (1992) Pituitary adenylate cyclase activating polypeptide (PACAP) reduces food intake in mice. Peptides 13:1133-1135.

Morley JE, Kumar VB, Mattammal M, Villareal DT (1995) Measurement of nitric oxide synthase and its mRNA in genetically obese $(\mathrm{ob} / \mathrm{ob})$ mice. Life Sci 57:1327-1331.

Mounien L, Bizet P, Boutelet I, Gourcerol G, Fournier A, Vaudry H, Jégou S (2006) Pituitary adenylate cyclase-activating polypeptide directly modulates the activity of proopiomelanocortin neurons in the rat arcuate nucleus. Neuroscience 143:155-163.

Mounien L, Do Rego JC, Bizet P, Boutelet I, Gourcerol G, Fournier A, Brabet P, Costentin J, Vaudry H, Jégou S (2009) Pituitary adenylate cyclaseactivating polypeptide inhibits food intake in mice through activation of the hypothalamic melanocortin system. Neuropsychopharmacology 34:424-435.

Nomura M, Ueta Y, Serino R, Kabashima N, Shibuya I, Yamashita H (1996) PACAP type I receptor gene expression in the paraventricular and supraoptic nuclei of rats. Neuroreport 8:67-70.

Pelleymounter MA, Cullen MJ, Baker MB, Hecht R, Winters D, Boone T, Collins F (1995) Effects of the obese gene product on body weight regulation in ob/ob mice. Science 269:540-543.

Pinto S, Roseberry AG, Liu H, Diano S, Shanabrough M, Cai X, Friedman JM, Horvath TL (2004) Rapid rewiring of arcuate nucleus feeding circuits by leptin. Science 304:110-115.

Saper CB, Chou TC, Elmquist JK (2002) The need to feed: homeostatic and hedonic control of eating. Neuron 36:199-211.

Schwartz MW, Porte D Jr (2005) Diabetes, obesity, and the brain. Science 307:375-379.

Schwartz MW, Seeley RJ, Campfield LA, Burn P, Baskin DG (1996) Identification of targets of leptin action in rat hypothalamus. J Clin Invest 98:1101-1106.

Schwartz MW, Erickson JC, Baskin DG, Palmiter RD (1998) Effect of fasting and leptin deficiency on hypothalamic neuropeptide $\mathrm{Y}$ gene transcription in vivo revealed by expression of a lacZ reporter gene. Endocrinology 139:2629-2635.

Seeley RJ, Yagaloff KA, Fisher SL, Burn P, Thiele TE, van Dijk G, Baskin DG, Schwartz MW (1997) Melanocortin receptors in leptin effects. Nature 390:349.

Segal JP, Stallings NR, Lee CE, Zhao L, Socci N, Viale A, Harris TM, Soares MB, Childs G, Elmquist JK, Parker KL, Friedman JM (2005) Use of laser-capture microdissection for the identification of marker genes for the ventromedial hypothalamic nucleus. J Neurosci 25:4181-4188.

Spiegelman BM, Flier JS (2001) Obesity and the regulation of energy balance. Cell 104:531-543.

Tachibana T, Saito S, Tomonaga S, Takagi T, Saito ES, Boswell T, Furuse M (2003) Intracerebroventricular injection of vasoactive intestinal peptide and pituitary adenylate cyclase-activating polypeptide inhibits feeding in chicks. Neurosci Lett 339:203-206.

Tachibana T, Saito ES, Takahashi H, Saito S, Tomonaga S, Boswell T, Furuse M (2004) Anorexigenic effects of pituitary adenylate cyclase-activating polypeptide and vasoactive intestinal peptide in the chick brain are mediated by corticotrophin-releasing factor. Regul Pept 120:99-105

Thornton JE, Cheung CC, Clifton DK, Steiner RA (1997) Regulation of hypothalamic proopiomelanocortin mRNA by leptin in ob/ob mice. Endocrinology 138:5063-5066.

Tong Q, Ye C, McCrimmon RJ, Dhillon H, Choi B, Kramer MD, Yu J, Yang Z, Christiansen LM, Lee CE, Choi CS, Zigman JM, Shulman GI, Sherwin RS, Elmquist JK, Lowell BB (2007) Synaptic glutamate release by ventromedial hypothalamic neurons is part of the neurocircuitry that prevents hypoglycemia. Cell Metab 5:383-393.

Uehara Y, Shimizu H, Ohtani K, Sato N, Mori M (1998) Hypothalamic corticotropin-releasing hormone is a mediator of the anorexigenic effect of leptin. Diabetes 47:890-893.

Vaudry D, Gonzalez BJ, Basille M, Yon L, Fournier A, Vaudry H (2000) Pituitary adenylate cyclase-activating polypeptide and its receptors: from structure to functions. Pharmacol Rev 52:269-324.

Zhang Y, Proenca R, Maffei M, Barone M, Leopold L, Friedman JM (1994) Positional cloning of the mouse obese gene and its human homologue. Nature 372:425-432.

Zhao L, Bakke M, Hanley NA, Majdic G, Stallings NR, Jeyasuria P, Parker KL (2004) Tissue-specific knockouts of steroidogenic factor 1. Mol Cell Endocrinol 215:89-94. 